\title{
Two new species of the genus Scathophaga (Diptera: Scathophagidae) from Svalbard, with a key to selected northern species and comments on their taxonomy
}

\author{
František Šifner
}

V štíhlách 1311, 14200 Praha 4, Czech Republic

\begin{abstract}
Šifner F., 2018: Two new species of the genus Scathophaga (Diptera: Scathophagidae) from Svalbard, with a key to selected northern species and comments on their taxonomy. - Journal of the National Museum (Prague), Natural History Series 187: 27-46.
\end{abstract}

\begin{abstract}
Two new Palaearctic species, Scathophaga annae sp. nov. and Scathophaga simaceki sp. nov. are described from Svalbard. An illustrated identification key for selected northern species from of the genus Scathophaga from the Palaearctic and Nearctic Regions is given. Two new combinations are provided: Coniostenum molle (Becker,1894) comb.nov. for Scathophaga mollis (Becker, 1894) and Coniosternum nigripalpis (Becker, 1907) comb. nov. for Scathophaga nigripalpis (Becker, 1907). Two new synonyms are established, Scathophaga (Coniosternum) sychevskaye Ozerov, 2010, syn. nov. = Coniosternum molle and Scathophaga minuta (Maloch, 1935), syn. nov. = Coniosterum lapponicum Ringdahl, 1920. Scathophaga islandica (Becker, 1894) and Scathophaga villipes (Zetterstedt, 1846) are confirmed as valid species. The species Scathophaga furcata (Say, 1823) is confirmed again in this area. Scathophaga janmayeni (Séguy, 1939 ) is species incertae sedis. Scathophaga islandica (Becker, 1894) is first recorded from Greenland and Sweden (Lappland).
\end{abstract}

Keywords: Taxonomy, new combinations, new species, new synonymy, Diptera, Scathophagidae, Coniosternum, Scathophaga, Nearctic Region, Palaearctic Region

Received: July 25, 2017 | Accepted: November 10, 2017 | Issued: December 31, 2018

\section{Introduction}

The genus Scathophaga Meigen, 1803 (type species Musca merdaria Fabricius, $1794=$ Musca stercoraria Linnaeus, 1758, by monotypy; the name Scopeuma Meigen, 1800 was suppressed by ICZN (1963): Opinion 678), is a widely distributed genus that comprises 54 species in the Palaearctic and Nearctic Regions (Šifner 2008, 2011, Ozerov 2014). Some of these species extend in the subarctic and arctic zones of both regions, approximately from $62^{\circ}$ to $72^{\circ} \mathrm{N}$, including Siberia, North Europe, Svalbard, Jan Mayen Island, Iceland, Faroe Islands, Greenland, Canadian Arctic Archipelago and Alaska. The distribution of Scathophagidae in arctic Canada was presented by Vockeroth (1956). The climatic conditions in the arctic and subarctic zones of the Palaearctic and Nearctic Regions are very specific; these conditions facilitate the development of endemic species. However, the taxonomic status of several species described from arctic regions remains unclear. 
In Svalbard, the occurrence of only two species, Scathophaga furcata (Say, 1823) and Scathophaga litorea (Fallén, 1819), was reliably confirmed (cf. Teschner, 1965). However, examination of newly collected material from Svalbard revealed that two additional new species have been discovered, and they are described in this paper: Scathophaga annae sp. nov. and Scathophaga simaceki sp. nov. To distinguish the new species and provide the key, I compared them with 13 northern species and 4 additional widely distributed Palaearctic species previously classified in the genus Scathophaga. The conducted study of the male and female terminalia further facilitates transfer of two species from Scathophaga into the genus Coniosternum, and synonymization of two other species.

\section{Material and methods}

In the text of comments, I complete descriptions of all the species in the following way: figures of males (abdominal sternites 5 or 5 and 4 (3), cerci and surstyli in caudal or lateral views and shape of pregonite, figures of female (abdominal sternites 8 to 6 (5)), and data on their distribution including original data from literature.

\section{The following acronyms of collections are used in the text:}

FSPC František Šifner private collection (will be deposited in the collection of National Museum, Praha, Czech Republic);

NHMW Naturhistorisches Museum, Wien, Austria;

MNHB Museum für Naturkunde der Humbolt-Universität, Berlin, Germany.

\section{Taxonomy}

\section{Key to some northern species of the genus Scathophaga}

$1 \quad$ Arista plumose. 2

- $\quad$ Arista bare. 7

$2 \quad$ Scape, pedicellus and first flagellomere brown. 3

- $\quad$ Scape, pedicellus and first flagellomere black. 6

3 Both cross-veins darkened. 4

- $\quad$ Both cross-veins not darkened. 5

4 Male abdominal sternite 5 without lobes, only two submedian processes developed, without short bristles, only with long and fine bristles latero-caudally (Fig. 24), pregonite wide with one apical seta and four dorsal setae (Fig. 26), female abdominal sternites 7 to 4 with two bristles latero-caudally (Fig. 27). S. incola (Becker, 1900)

Male abdominal sternite 5 without lobes, only two submedian processes developed, with short bristles and with fine long bristles caudally (Fig. 52), pregonite with one apical seta and six dorsal setae (Fig. 53), female abdominal sternite 7 divided into two separate sclerites (Fig. 54). S. suilla (Fabricius, 1794)

5 Two submedian processes not developed (Fig. 55), only with long and fine bristles latero-caudally, pregonite with four long apical setae (Fig. 56). S. Iutaria (Fabricius, 1794)

- $\quad$ Two submedian processes distinctly developed. 6

6 Both cross-veins only very small, darkened, submedian processes of male abdominal sternite 5 with short bristles caudally (Fig. 57), pregonite narrow with three bristles (Fig. 58), female abdominal sternite 7 divided into three separate sternites (Fig. 59). S. stercoraria (Linnaeus, 1758). 
Both cross-veins not darkened, submedian processes of male abdominal sternite 5 with long bristles caudally (Fig. 16), pregonite with four dorsal setae (Fig. 17), female abdominal sternites 8 narrow and long (Fig. 19). S. cordilurina (Holmgren, 1883)

Scape, pedicellus and first flagellomere brown. $\quad 8$ Scape, pedicellus and first flagellomere black. 9

Both cross-veins darkened, first femora dark or only with dark strips dorsally, only two submedian processes developed, bearing short bristles (Fig. 63), pregonite with four setae (Fig. 64), female abdominal sternite 7 divided into three separate sclerites (Fig. 65). S. furcata (Say, 1823)

Both cross-veins distinctly and widely darkened, first femora brown, two submedian processes with short bristles (Fig. 1), pregonite wide with three apical long setae and two very short lateral setae (Fig. 4). S. annae sp. nov. Body and all legs haired. 10 Body and all legs not haired. 11

10 Pregonite of male with two apical setae (Fig. 10), male sternites 5 to 3 bristled laterally (Fig. 8), cerci wide (Fig. 9), female abdominal sternite 7 circular, sternite 6 narrowed proximally (Fig. 11). S. apicalis (Curtis, 1835) Pregonite of male with one apical seta and four dorsal setae (Fig. 42), female abdominal sternites 8 pointed apically, sternite 7 indented caudally (Fig. 43). S. multisetosa (Holmgren, 1883)

\section{2, 32, 48). 12} Male abdominal sternite covered by very small and rare bristles (Fig. 44), cerci narrow and pointed apically (Fig. 45), female abdominal sternite 7 wide caudally, sternites 6 and 5 oval (Fig. 47). S. varipes (Holmgren, 1883)

Lobe of male sternite 5 bristled only shortly interiorly (Fig. 12), female abdominal sternite 7 divided into two separate sclerites (Fig. 15). S. calida (Holiday, 1832) Lobes of male abdominal sternite 5 haired or bristled, female abdominal sternite 7 not divided. 13

13 Surstyli of male very strongly arched inwards, female abdominal sternites are in one piece and of different shape, male pregonites slightly arched and narrowed apically. 14

Surstyli of male more or less straight, pointed or widened, female abdominal sternites rounded, male pregonites more or less straight and rounded apically. 15 Surstyli of male forked, cerci arched apically and without bristles at the end (Fig. 33), pregonite with one dorsal and one apical seta (Fig. 34), female abdominal sternite 7 rectangular and in apical half bristled (Fig. 35). S. islandica (Becker, 1894)

- $\quad$ Surstyli of male pointed, cerci wide (Fig. 50), pregonite with one subdorsal and one apical seta (Fig. 49), female abdominal sternite 7 small and only sparsely bristled (Fig. 51). S. villipes (Zetterstedt, 1846)

15 Surstyli of male always pointed apically. 16

- $\quad$ Surstyli of male widened apically (Fig. 60), pregonite with two setae (Fig. 61), female abdominal sternites 6 and 7 more or less circular, sternites 8 pointed caudally and sparsely bristled (Fig. 62). S. obscurinervis (Becker, 1900)

16 Pregonite of male with two setae, one apical and one latero-apical (Fig. 38), cerci widened apically and bristled (Fig. 37), female abdominal sternite 7 quadrate (Fig. 39). S. litorea (Fallén, 1819)

- $\quad$ Pregonite of male with one apical seta. 17

17 Lobes of male abdominal sternite 5 arched apically outside, sternites 4 and 3 rectangular (Fig. 28), cerci wide and with double row of short bristles (Fig. 29), fe- 
male abdominal sternite 7 oval, sternite 6 also oval and very slightly sclerotized marginally (Fig. 31). S. intermedia (Walker, 1849)

Lobes of male abdominal sternite 5 rounded apically (Fig. 5), cerci wide and bristled only basally (Fig. 6). S. simaceki sp. nov.

\section{Descriptions of new species}

\section{Scathophaga annae sp. nov.}

Type material. Holotype: $\mathrm{m}^{*}$, Svalbard, Spitsbergen Island, locality Pyramiden, $78^{\circ} 39^{\prime} 22^{\prime \prime} \mathrm{N}$ $16^{\circ} 19^{\prime} 30^{\prime \prime} \mathrm{E}, 15 . v i i i .2015$, Anna Mácová leg. (FCPC).

Description. Male. Body length $10 \mathrm{~mm}$, primary coloration brown.

Head completely brown, orbits and genae, frontal vitta and parafacials yellowish-brown, pedicellus and first flagellomere brown, arista bare and thickened in first half, palpi yellowish-brown, vibrissal callus with one strong and two short bristles.

Thorax. Chaetotaxy standard for the genus, acrostichal bristles very rare, one supraalar bristle, two intraalar bristles, basal and apical scutellar bristles of equal size, both cross-veins with large dark coloration, all legs including coxae and all tarsomeres brown.

Abdomen. Sternite 5 without lobes and with only two short submedian processes covered with very short black bristles, sternite 4 rectangular with distinct processes proximally, sternite 3 also rectangular (Fig. 1), cerci long, oval and with short bristles only basally, surstyli straight, slightly arched from lateral view, pointed apically and without sclerotisation (Fig. 2), pregonite large with three setae apically and with very short setae latero-apically (Fig. 4), postgonites narrow, straight and long, epiphallus very short (Fig. 3).

Female unknown.

Differential diagnosis. See the key below.

Etymology. The name of this species is derived from the first name of Miss Anna Mácová, first collector of the new species (Veselí nad Lužnicí, Czech Republic).

Distribution. Known only from Svalbard.
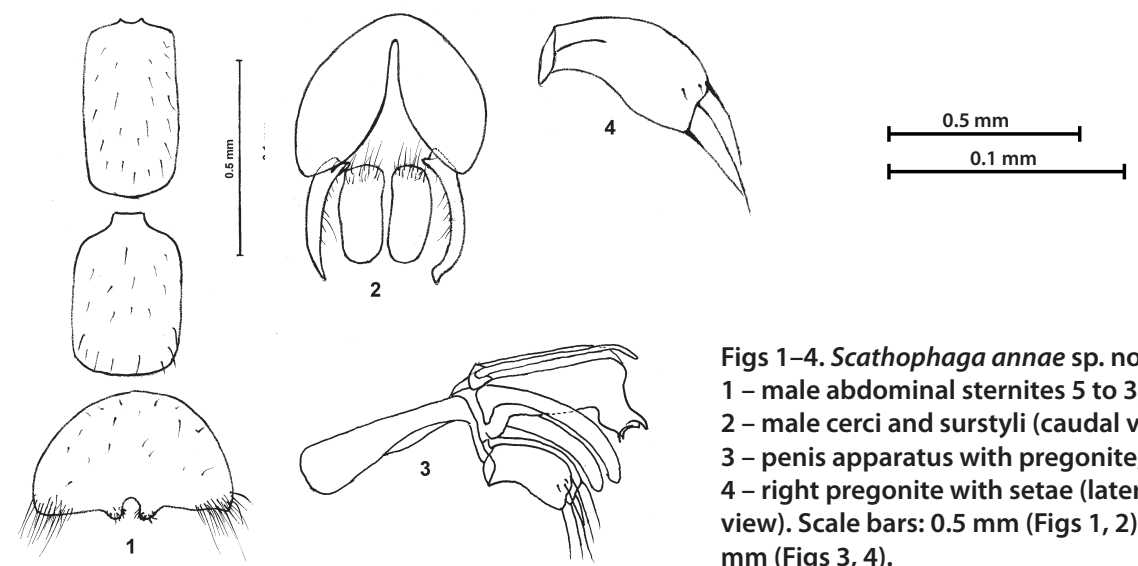

Figs 1-4. Scathophaga annae sp. nov. 1 - male abdominal sternites 5 to 3; 2 - male cerci and surstyli (caudal view); 3 - penis apparatus with pregonite; 4 - right pregonite with setae (lateral view). Scale bars: $0.5 \mathrm{~mm}$ (Figs 1, 2); 0.1 mm (Figs 3, 4). 
Type material. Holotype: $\mathrm{m}^{*}$, Svalbard, Spitsbergen Island, locality Pyramiden, $78^{\circ} 39^{\prime} 22^{\prime \prime} \mathrm{N}$ $16^{\circ} 19^{\prime} 30^{\prime \prime}$ E, 15.viii.2016, Anna Mácová leg. (FSPC).

Description. Male. Body length $8 \mathrm{~mm}$, primary coloration dark to black.

Head completely dark to black, slightly dusted including face, orbits and genae, frontal vitta brown only in frontal portion, pedicel and first flagellomere black, arista bare and thickened in first quarter, palpi yellowish-brown, vibrissal callus with two fine bristles, lower part of genae with two rows of short bristles.

Thorax. Chaetotaxy standard for the genus, basal and apical scutellar bristles of equal size, two long supraalar bristles, both cross-veins without dark coloration, wings slightly but distinctly darkened, all legs including all tarsomeres black.

Abdomen. Sternite 5 with straight lobes, medially covered with short bristles, sternites 4 and 3 rectangular without distinct bristles (Fig. 5), cerci roughly rectangular with bristles basally, surstyli slightly arched in caudal view and pointed, without bristles (Fig. 6), pregonite slightly arched with one dorsal seta, epiphallus distinct and pointed (Fig. 7).

Female unknown.

Differential diagnosis. See the key below.

Etymology. I dedicate this species to my friend Milan Šimáček (Unhošt', Czech Republic).

Distribution. Known only from Svalbard.
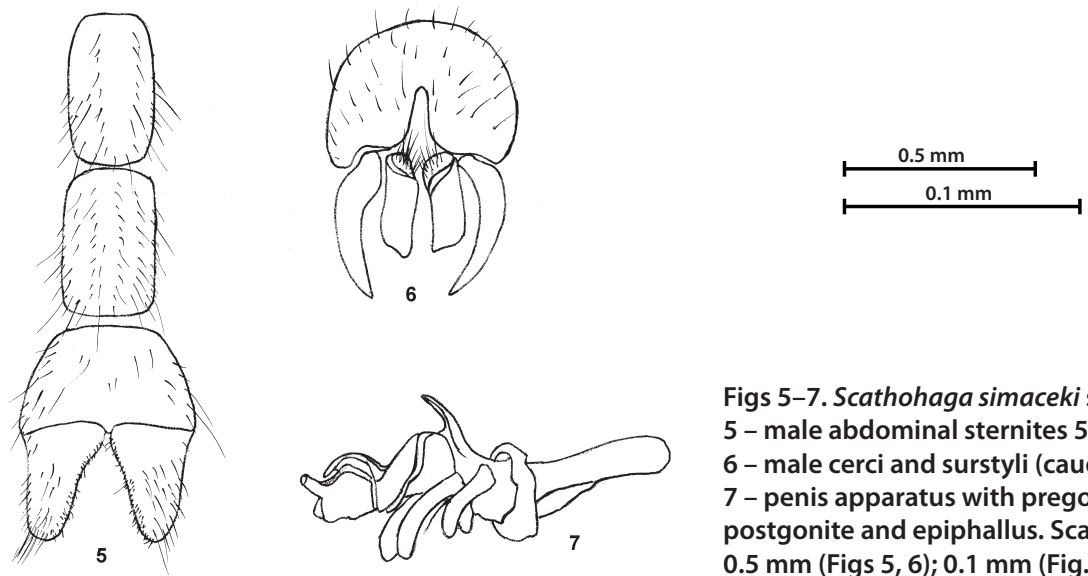

Figs 5-7. Scathohaga simaceki sp. nov.. 5 - male abdominal sternites 5 to 3 ; 6 - male cerci and surstyli (caudal view); 7 - penis apparatus with pregonite, postgonite and epiphallus. Scale bars: $0.5 \mathrm{~mm}$ (Figs 5, 6); $0.1 \mathrm{~mm}$ (Fig. 7).

\section{Review of the northern species of Scathophaga}

\section{Scathophaga apicalis (Curtis 1835)}

Scathophaga apicalis Curtis, 1835 in Ross (1835: lxxx)

Scatophaga lanata Lundbeck, 1917: 294 (synonymized by Vockeroth 1965: 858)

Scatophaga nigrolanata Cresson, 1898: 136 (syn. by Vockeroth 1965: 868)

Scatophaga rubicunda Malloch, 1919: 81 (syn. by Vockeroth 1965: 868) 
Material examined. CANADA: Clyde, Baffin Is., N.W.T., 25.viii.1958, 1 m*, ibid., 25.vii.1958, $1 \mathrm{f*}$, all J. E. H. Martin leg., J. R. Vockeroth det. as S. apicalis (FSPC).

Diagnosis. Male. Abdominal sternites 4 and 3 oval, lobes of sternite 5 straight, pointed apically, all sternites only haired (Fig. 8), cerci arched with long hairs, surstyli narrow and slightly forked apically in lateral view (Fig. 9), pregonite arched with short latero-apical bristles and one long apical bristle (Fig. 10). Female. Abdominal sternite 7 almost round, sternite 6 oval with a process proximally, sternite 5 oval, sternites 8 oval and narrowed caudally, all sternites with long and distinct bristles (Fig. 11).
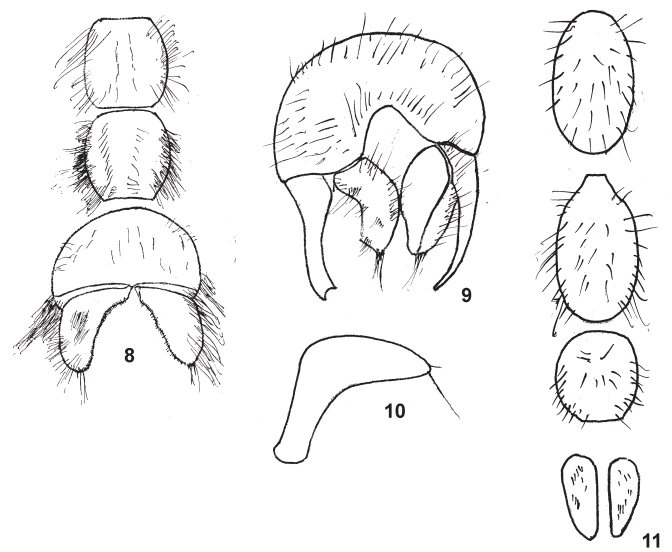

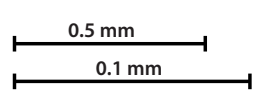

Figs 8-11. Scathophaga apicalis (Curtis, 1835). 8 - male abdominal sternites 5 to $3 ; 9$ - male cerci and surstyli (caudal view); 10 - right pregonite; 11 - female abdominal sternites 8 to 5 . Scale bars: $0.5 \mathrm{~mm}$ (Figs 8, 9, 11); $0.1 \mathrm{~mm}$ (Fig. 10).

Distribution. Canada (Malloch 1935); Greenland (Hansen \& Lundbeck 1917, Vockeroth 1965, Michelsen 2006); Russia (Ozerov 2013).

\section{Scathophaga calida (Haliday, 1832)}

Scatophaga calida Haliday, 1832: in Curtis (1832: 405)

Material examined. UNITED KINGDOM: Scotland, West Lath., Ocean Sea, 11.viii., 1 m*; Culture, Queens, 8.iv., $1 \mathrm{f}^{*}$, Nelson leg., Nelson det. as $S$. calida (FSPC).

Diagnosis. Male. Abdominal sternites 4 to 3 more or less rectangular, sternite 4 with a process proximally, lobes of sternite 5 arched and covered with short bristles, laterally with long hairs (Fig. 12), cerci in upper portion with long bristles, surstyli short and pointed (Fig. 13), pregonite wide with one dorsal seta and one apical seta (Fig. 14). Female. Abdominal sternite 7 divided into two separate and slightly sclerotized sclerites, sternite 6 rectangular, sternites 8 triangular and small (Fig. 15).

Distribution. Ireland (Haliday 1832, Chandler 1998); United Kingdom (Chandler 1998), Iceland (Nielsen et al. 1954), Norway (Nelson \& Greve 2002), Sweden (Hedström 1991), Russia (Lindroth 1931). 


\section{Scathophaga cordylurina (Holmgren, 1883)}

Scatomyza cordylurina Holmgren, 1883: 173.

Scopeuma longiqua Becker, 1915: 66 (syn. Gorodkov 1986: 30)

Material examined. RUSSIA: West Yamal peninsula, 18.vi.1994, $1 \mathrm{~m}^{*} 1 \mathrm{f} *$, Bengtson leg., Engelmark det. as $S$. cordylurina (FSPC).

Diagnosis. Male. Abdominal sternites 4 and 3 oval, both slightly sclerotized caudally, sternite 5 without lobes and with only short submedian processes covered by short bristles, laterally from processes with long hairs (Fig. 16), cerci and surstyli almost of equal size, cerci almost without bristles, surstyli pointed and medially with long hairs (Fig. 17), pregonite with one apical seta and a row of four dorsal short setae (Fig. 18). Female. Abdominal ster-

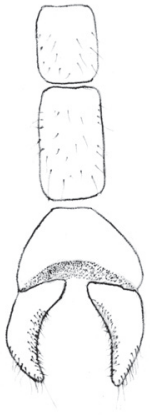

12
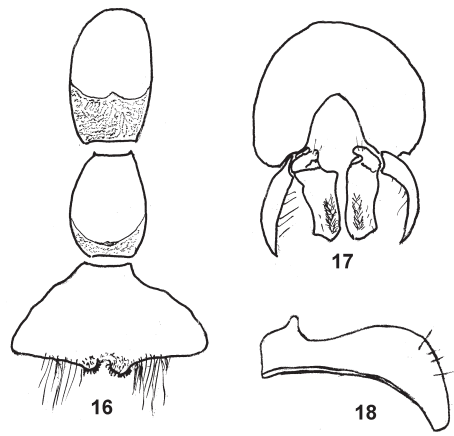
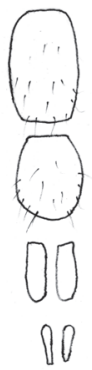

15
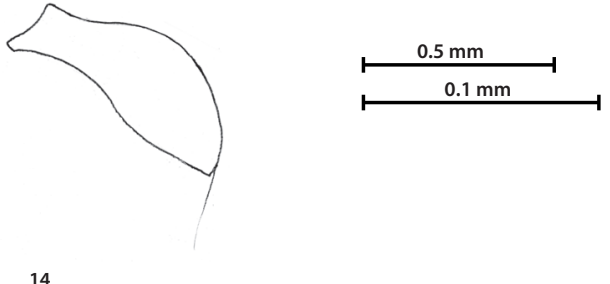

Figs 12-15. Scathophaga calida (Haliday, 1832). 12 - male abdominale sternites 5 to $4 ; 13$ male cerci and surstyli (caudal view); 14 - right pregonite with one apical seta; 15 - female abdominal sernites 8 to 5 . Scale bars: $0.5 \mathrm{~mm}$ (Figs 12, 13, 15); $0.1 \mathrm{~mm}$ (Fig. 14).

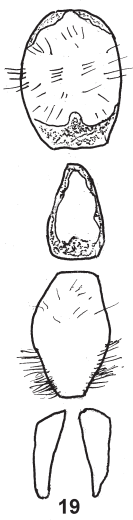

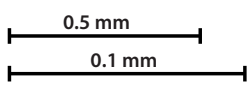

Figs 16-19. Scathophaga cordylurina (Holmgren, 1883). 16 - male abdominal sternites 5 to $3 ; 17$ - male cerci and surstyli (caudal view); 18 - right pregonite with four latero-dorsal setae; 19 - female abdomnal sternites 8 to 5 . Scale bars: $0.5 \mathrm{~mm}$ (Figs 16, 17, 19); 0.1 $\mathrm{mm}$ (Fig. 18).

nites 8 long, pointed caudally, sternite 7 narrowed and caudally with strong bristles, sternite 6 without bristles and weakly sclerotized marginally, sternite 5 oval, bristled and weakly sclerotized caudally (Fig. 19).

Distribution. Russia (Gorodkov 1986). 


\section{Scathophaga crinita (Coquillett, 1901)}

Scatophaga crinita Coquillett, 1901: 612.

Material examined. USA: St. Matthew Is., Bering Sea, 24.viii.1954, 1 m*, the same locality, 19.viii.1954, 1 f*, all Rausch leg., J. R. Vockeroth det. as S. crinita (FSPC).

Diagnosis. Male. Lobes of abdominal sternite 5 wide, medially shortly bristled with long hairs laterally, sternite 4 distinctly quadrate, sternite 3 rectangular (Fig. 20), cerci oval and long haired, distyli wide and forked apically (Fig. 21), pregonite wide with one seta apically (Fig. 22). Female. Abdominal sternites 8 very small, sternite 7 distinctly quadrate, sternite 6 indented caudally (Fig. 23).

Distribution. Canada (Malloch 1935), USA (Malloch 1935), Russia: Far East (Gorodkov 1986).
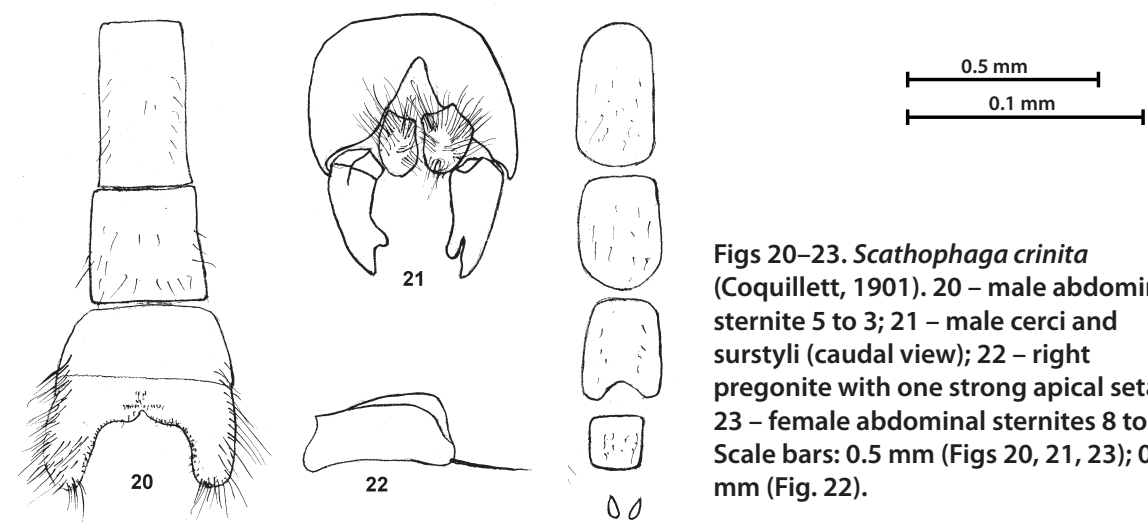

Figs 20-23. Scathophaga crinita (Coquillett, 1901). 20 - male abdominal sternite 5 to $3 ; 21$ - male cerci and surstyli (caudal view); 22 - right pregonite with one strong apical seta; 23 - female abdominal sternites 8 to 4 . Scale bars: $0.5 \mathrm{~mm}$ (Figs 20, 21, 23); 0.1 mm (Fig. 22).

23

\section{Scathophaga furcata (Say, 1823)}

Pyropa furcata Say, 1823: 98.

Scatophaga squalida Meigen, 1826: 252 (syn. by Ringdahl 1936: 171)

Scatina claripennis Robineau-Devoidy, 1830:629 (syn. by Šifner 2008: 163)

Scatomyza fuscinervis Zetterstedt, 1838: 722 (syn. by Pandellé 1904: 26)

Scatophaga nigricans Macquart, 1835: 395 (syn. by Becker 1905: 10)

Scatophaga limbata von Roser, 1840: 60 (syn. by Šifner 2008: 163)

Scatophaga pubescens Walker, 1849: 982 (syn. by Vockeroth 1965: 838)

Scatophaga bicolor Walker, 1849: 982 (syn. by Vockeroth 1965: 838)

Scatophaga canadensis Walker, 1858: 218 (syn. by Vockeroth 1965: 838)

Cleigastra suisterei Townsend, 1891: 153 (syn. by Vockeroth 1965: 838)

Scatophaga semiatra de Meijere, 1907: 181 (syn. by de Jong 2000: 154)

Scatophagella pubescens Szilády, 1926: 597 (syn. by Šifner 2008: 163)

Material examined. NORWAY: Spitzbergen, loc. Pyramiden, 15.viii.2016, 2 m*m*, A. Mácová leg. (FSPC).

Distribution. Whole Palaearctic region including Japan (cf. Šifner 2008: 163-164); 
Nearctic Region (Vockeroth 1965).

Comment. Confirmed occurrence in Spitzbergen.

\section{Scathophaga incola (Becker, 1900)}

Scatophaga incola Becker, 1900: 54.

Scopeuma fascifrons Ringdahl, 1936: 174 (syn. Hackman 1980: 131)

Material examined. SWEDEN: Lu 1, Jokkmokk, 19.viii.1977, 1 m*, Lu 1, Kvikkjokk, 9.vii.1977, 1 f*, all R. E. leg., Anderson det. as S. incola (FSPC).

Diagnosis. Male. Abdominal sternite 5 oval with two short processes proximally, without lobes and with only two narrow submedian short processes, laterally with long hairs, sternites 4 and 3 more or less quadrate (Fig. 24), cerci and distyli long and almost of equal size, lateral portion of epandrium with long hairs (Fig. 25), pregonite wide, narrowed and arched

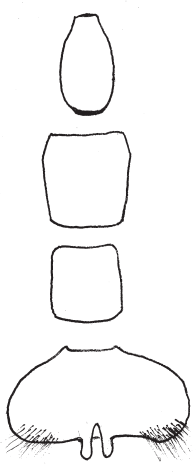

24
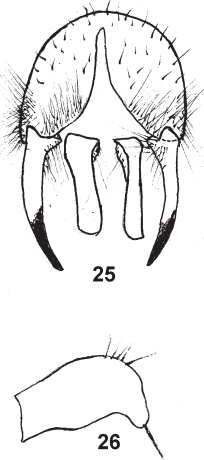

26

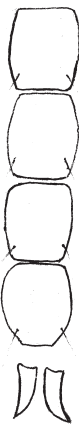

27

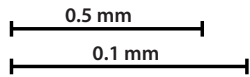

Figs 24-27. Scathophaga incola (Becker 1900). 24 - male abdominal sternites 5 to $2 ; 25$ - male cerci and surstyli (caudal view); 26 - right pregonite; 27 - female abdominal sternites 8 to 4 . Scale bars: $0.5 \mathrm{~mm}$ (Figs 24, 25, 26); $0.1 \mathrm{~mm}$ (Fig. 26).

apically, one apical and five dorsal setae (Fig. 26). Female. Abdominal sternites 8 narrow and pointed, sternites 7 to 4 more or less quadrate and all with two bristles latero-caudally (Fig. 27).

Distribution. Russia (Vockeroth 1965), USA (Vockeroth 1965), Canada (Vockeroth 1965), Finland (Hackman 1956), Sweden (Hedström 1991), Norway (Nelson \& Greve 2002), Russia (Gorodkov 1986), Spain (de Jong 2005).

\section{Scathophaga intermedia (Walker, 1849)}

Scatophaga intermedia Walker, 1849: 180.

Material examined. CANADA: Payne Bay, Que., 20.vii.1958, 1 m*; the same locality, 27.vii.1958, 1 f*, Mac Dougall leg., J. R. Vockeroth det. as S. intermedia (FSPC).

Diagnosis. Male. Abdominal sternite 5 with lobes slightly arched outside with one long caudal bristle, sternite 4 and 3 rectangular without distinct bristles (Fig. 28), cerci forked 

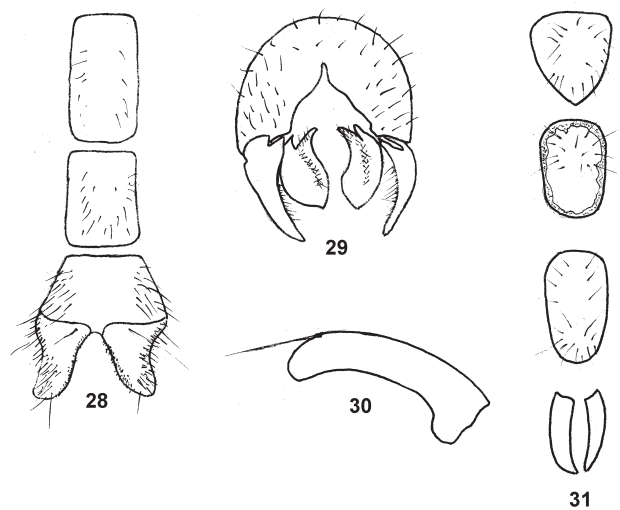

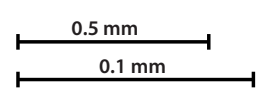

Figs. 28-31. Scathophaga intermedia (Walker, 1849). 28 - male abdominal sternites 5 to $3 ; 29$ - male cerci and surstyli (caudal view); 30 - left pregonite; 31 - female abdominal sternites 8 to 5 . Scale bars: $5 \mathrm{~mm}$ (Figs 28, 29, 31); 0.1 mm (Fig. 30).

basally and with two rows of bristles, distyli slightly arched with short fine bristles interiorly (Fig. 29), pregonite narrow with one dorsal seta (Fig. 30). Female. Abdominal sternites 8 narrow and pointed, sternites 7 to 5 more or less oval with distinct bristles, sternite 6 slightly sclerotized marginally (Fig. 31).

Distribution. Canada (Vockeroth 1965), Poland (Draber-Mońko 1991), Russia (Gorodkov 1986).

\section{Scathophaga islandica (Becker, 1894)}

Scatophaga islandica Becker, 1894: 175

Material examined. ICELAND: Iceland, 1 m*, coll. Loew, No 11452, det. Becker as S. islandica (NHMW). SWEDEN: Lappland, Tornekransk [= Torneträsk], $1 \mathrm{~m} *$, without data, male was dissected in 1975 (NHMW). GREENLAND: Groenland, $1 \mathrm{~m}^{*} 1 \mathrm{f}^{*}$, coll. Winthem, det. Becker (NHMW); Groenland, 1 f*, coll. Winthem, without data, female was dissected in 1975 (NHMW).

Diagnosis. Male. Abdominal sternite 5 with short and wide lobes basally, short bristles medially, lobes narrowed and rounded apically (Fig. 32), cerci long, narrowed apically and covered with very long hairs, surstyli slightly arched, pointed with a process interiorly (Fig. 33), pregonite with one dorsal and one apical seta, postgonite arched, epiphallus slightly arched and wide (Fig. 34). Female. Abdominal sternite 7 rectangular and indented caudally, sternite 6 distinctly rounded proximally, sternites 8 arched caudally and with very short bristles apically (Fig. 35). Collin (1935: 377, Fig. 5) first figured the shape of pregonite with two bristles.

Comments. This species was described in detail by Becker (1894) based on both sexes from Loew's collection. In the original description it was distinguished from S. litorea (Fallén, 1819) and S. villipes (Zetterstedt, 1846) (cf. Becker 1894: 175). The depository of the types is unknown, being missing in MNHB (Morge, pers. comm. 1975). The validity of this species was doubted, e.g. by Collin (1931) who stated: 'Probably islandica, Becker is a synonym of northern form (nigripes) of litorea'. Vockeroth (1965) mentioned: 'perhaps a mixture of litorea and intermedia'. James (1950) as first synonymized this species with S. litorea and also Gorodkov (1986); this information were accepted by Šifner (2008). Identical conclusions were expressed by Ozerov (2014). Collin (1935: 377, Fig. 5) was the first who figured the shape of pregonite with two bristles, i.e. one dorsal bristle and one apical bristle. Its figure 
is unambiguously identical with the Fig. 35 in the same paper. I confirm here Scathophaga islandica (Becker, 1894) as a valid species.

Distribution. Iceland (Becker 1894), Russia: Novaya Zemlya (Lindroth 1931), Alaska (Lindroth 1931), Canada: Labrador (Lindroth 1931), Pribilof Island in Canadian Arctic Archipelago (Malloch 1935), Greenland (this paper), Sweden: Lappland (this paper).
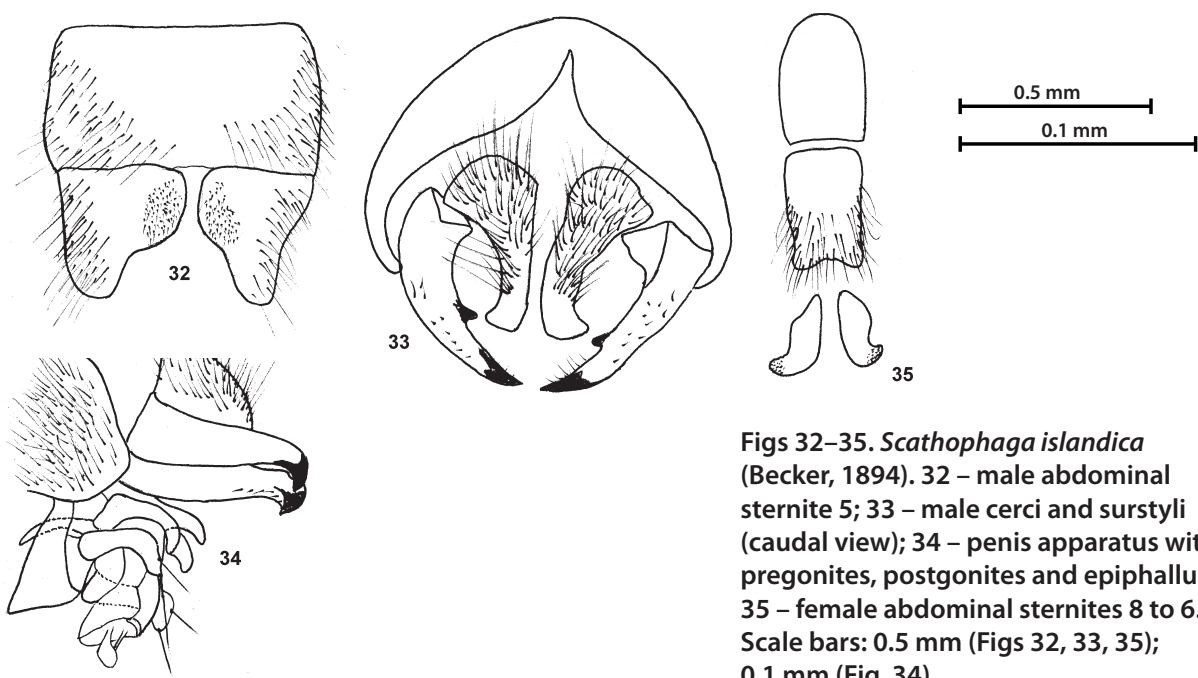

Figs 32-35. Scathophaga islandica (Becker, 1894). 32 - male abdominal sternite 5; 33 - male cerci and surstyli (caudal view); 34 - penis apparatus with pregonites, postgonites and epiphallus; 35 - female abdominal sternites 8 to 6 . Scale bars: $0.5 \mathrm{~mm}$ (Figs 32, 33, 35); $0.1 \mathrm{~mm}$ (Fig. 34).

\section{Scathophaga janmayeni (Séguy, 1938)}

Scatomyza janmajeni Séguy, 1938: 109

Comment. Originally described as Scatomyza Janmayeni from Jan Mayen Island, based on one female, according to differences in colouration. Šifner (2008) synonymized the species with $S$. litorea. However, the colouration is very variable and not suitable for species delimitation. Therefore I consider the species Scathophaga janmayeni (Séguy, 1938) as taxon incertae sedis.

\section{Scathophaga litorea (Fallén, 1819)}

Scatomyza litorea Fallén, 1819: 4

Scatophaga nigricornis Robineau-Desvoidy, 1830 (syn by Šifner 2008: 166)

Scatophaga bipunctata Macquart, 1835 (syn. by Šifner 2008: 166)

Scatophaga tesselata Macquart, 1838 (syn. by Šifner 2008: 166)

Anthomyia impudica Reiche, 1857 (syn. by Vockeroth 1965: 839)

Scatomyza hyperborea Boheman, 1866 (syn. by Šifner 2008: 166)

Scatina fontanalis Rondani, 1867 (syn. by Sack 1937: 62)

Scatomyza nigripes Holmgren, 1869 (syn. by Gorodkov 1986: 32)

Scatomyya stuxbergii Holmgre, 1880 (syn. by Gorodkov 1986: 32) 
Scatophaga islandica Becker, 1894 (syn. by James 1950: 350)

Scatophaga rufiventris Villeneuve, 1917 (syn. by Séguy 1934: 694)

Material examined. SWEDEN: Abisko, 1930, $1 \mathrm{~m}^{*} 1 \mathrm{f}^{*}$, leg.?, F. Šifner det. as S. litorea (NHMW).

Diagnosis. Male. Abdominal sternite 5 with lobes narrowed apically, medially with short and dense bristles, sternites 4 and 3 oval (Fig. 36), cerci long and long bristled, surstyli pointed (Fig. 37), pregonite narrow with one apical and one lateral setae (Fig. 38). Female. Abdominal sternites 8 wide and pointed apically, sternite 7 quadrate, sternite 6 rectangular and slightly narrowed proximally, all without distinct bristles (Fig. 39).

Distribution. Arctic Canada (Malloch 1935); Russia (Holmgren 1883), Hansen \& Lundbeck (1917), Lindroth (1931); Svalbard, Jan Mayen Island (Lindroth 1931); Greenland (Michelsen 2006); Iceland (Lindroth 1931). Further distributed in most of Europe, Far East of Russia, and Nearctic Region (cf. Šifner 2008: 166, Ozerov \& Krivosheina 2014: 218).
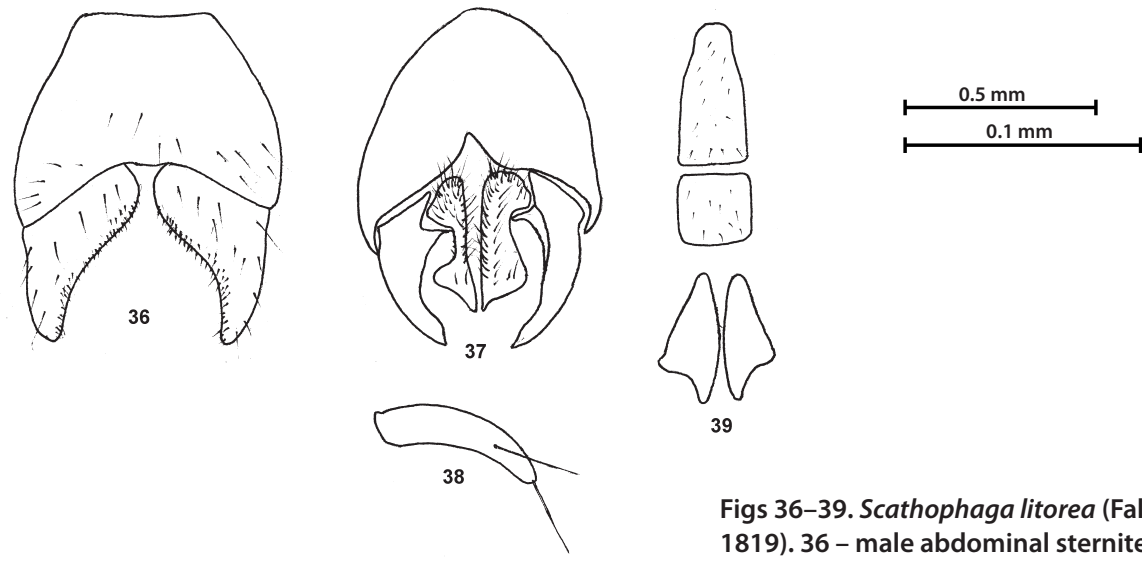

Figs 36-39. Scathophaga litorea (Fallén, 1819). 36 - male abdominal sternite $5 ; 37$ - male cerci and surstyli (caudal view); 38 - right pregonite; 39 - female abdominal sternites 8 to 6 . Scale bars: $0.5 \mathrm{~mm}$ (Figs 3, 37, 39); $0.1 \mathrm{~mm}$ (Fig. 38).

\section{Scathophaga multisetosa (Holmgren, 1883)}

Scatomyza multisetosa Holmgren, 1883: 174

Scatophaga arctica Becker, 1897: 398 (syn. by Gorodkov 1986: 29)

Scatophaga vulpina Coquillett, 1898: 162 (syn. by Vockeroth 1965: 839)

Material examined. CANADA: N.W.T., Ellesmere Is., Forsheim Peninsula, Hof Weather Creek, 23.vi.1990, $1 \mathrm{~m}^{*}$; the same locality, 1.vii.1991, $1 \mathrm{f}^{*}$, E. Brodo leg., J. R. Vockeroth det. as $S$. multisetosa (FSCP).

Diagnosis. Male. Lobes of abdominal sternite 5 wide, narrowed apically, hairy, medially with short bristles, sternites 4 and 3 more or less rectangular, sternite 4 slightly sclerotized caudally (Fig. 40), cerci wide, pointed apically, surstyli almost as long as cerci, interiorly densely haired (Fig. 41), pregonite with one apical and four dorsal setae (Fig. 42). Female. Abdominal sternites 8 long, pointed and bristled apically, sternites 7 and 6 oval with strong bristles (Fig. 43). 
Distribution. Canada (Vockeroth 1965); USA (Coquillett 1898, Malloch 1935); Russia (Becker 1897, Ozerov and Krivosheina 2013).

Comments. Gorodkov (1986) synonymized Scathopaga arctica Becker, 1897 with species $S$. multisetosa (Holmgren, 1883). The synonymy with S. apicalis (Curtis, 1835) listed by Šifner (2008) was an error.
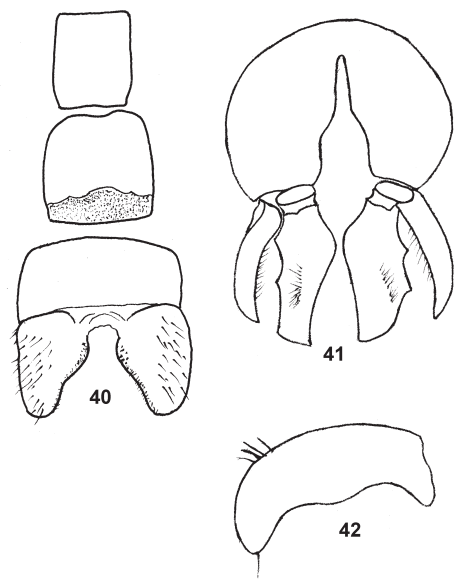

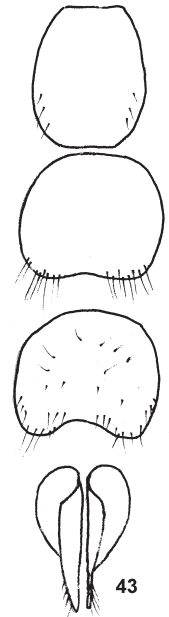

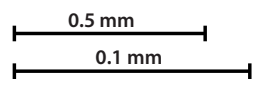

Figs 40-43. Scathophaga multisetosa (Holmgren, 1883). 40 - male abdominal sternites 5 to $3 ; 41$ - male cerci and surstyli (caudal view); 42 - left pregonite; 43 - female abdominal sternites 8 to 5 . Scale bars: $0.5 \mathrm{~mm}$ (Figs 40, 41, 43); $0.1 \mathrm{~mm}$ (Fig. 42).

\section{Scathophaga obscurinervis (Becker, 1900)}

Scathophaga obscurinervis Becker, 1900: 55

Scatophaga futilis Malloch, 1935: 264 (syn. Vockeroth: 1965: 839)

Material examined. RUSSIA: Ins. Nikadr [= Insel Nikander], obscurinervis Becker, J. Sahlberg, No. 42483, 1 m* (NHMW). SWEDEN: Abisko, vii., 1 f*, leg.?, J. R. Vockeroth as $S$. obscurinervis det. (NHMW).

Distribution. Finland (Hackman 1980), Norway (Nelson \& Greve 2002), Russia (Gorodkov 1986), Sweden (Hedstrom 1991. Nearctic Region (Vockeroth 1965).

\section{Scathophaga varipes (Holmgren, 1883)}

Scatomyza varipes Holmgren, 1883: 175

Scatophaga septentrionalis Becker, 1897 (syn. Gorodkov 1986: 34)

Scatophaga nubifera Coquillett, 1901: 612 (syn. Vockeroth 1965: 839)

Material examined. RUSSIA: West Yamal peninsula, 13.vi.1994, $1 \mathrm{~m} *$, Bengston leg., Engelmark det. as S. varipes (FSCP). CANADA: Bailey Point, Melville Is., N.W.T., 21.vii.1965, J. E. M. Martin lgt.; 1 f*, J. R. Vockeroth det. as $S$. varipes (FSCP).

Diagnosis. Male. Lobes of abdominal sternite 5 wide, sparsely haired and rounded apically, sternite 4 quadrate, sternite 3 rectangular (Fig. 44), cerci long, narrowed and pointed apically, epandrium with dense hairs (Fig. 45), pregonite small with two apical setae (Fig. 46). Female. Abdominal sternite 7 wide caudally, sternites 5 and 6 oval, sternites 8 arched 
apically and pointed (Fig. 47).

Distribution. Russia (Ozerov 2013); Canada (Vockeroth 1965); USA (Coquillett (1901).

\section{Scathophaga villipes (Zetterstedt, 1846)}

Scatomyza villipes Zetterstedt, 1846: 1977

Material examined. FINLAND: Peisamo, 13.-14.vii.1929, 1 m*, Frey leg., W. Hackman det. as $S$. villipes (NHMW). ICELAND: Forsvögur, 12.viii.1948, 1 f*, Slípka leg., F. Šifner det. as $S$.

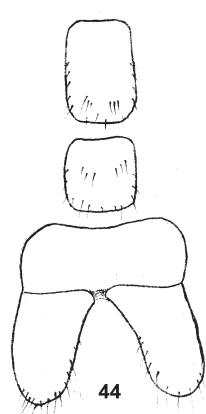

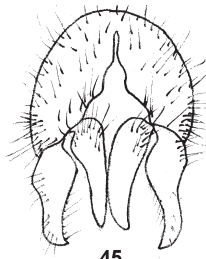

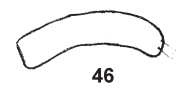

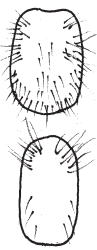
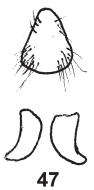

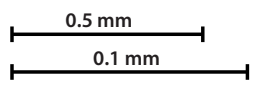

Figs 44-47. Scathophaga varipes (Holmgren, 1883). 44 - male abdominal sternites 5 to $3 ; 45$ - male cerci and surstyli (caudal view); 46 - right pregonite; 47 - female abdominal sternite 8 to 5 . Scale bars: $0.5 \mathrm{~mm}$ (Figs 44, 45, 47); $0.1 \mathrm{~mm}$ (Fig. 46).

villipes (FSPC).

Diagnosis. Male. Abdominal sternite 4 oval, lobes of sternite 5 long and densely hairy, pointed apically (Fig. 48), epandrium and cerci with long hairs, surstyli short and sclerotized only apically (Fig. 49), pregonite with one apical and subdorsal setae, postgonite long and arched, epiphallus pointed (Fig. 50).

Distribution. Finland, Sweden, along Norwegian coast, along the coast of the Arctic Ocean to Siberia (Lindroth 1931, Hackman 1956), Faroe Islands (Hansen 1881).

Comments. Šifner (2008) accepted the synonymy proposed Gorodkov (1986). The vali-
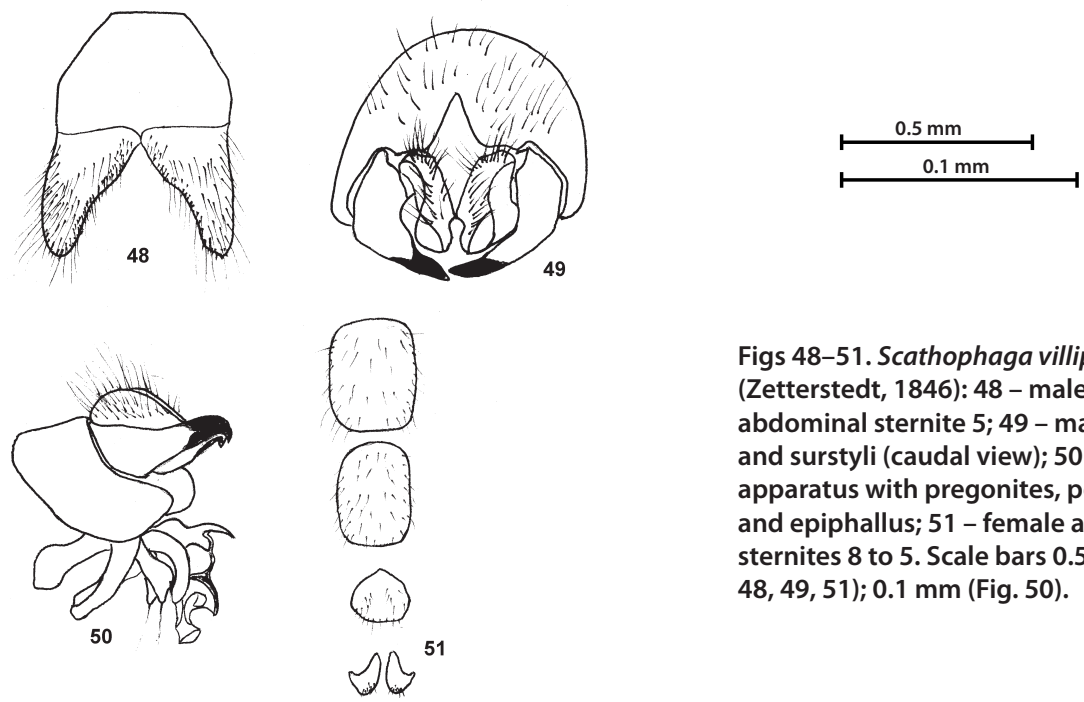

Figs 48-51. Scathophaga villipes (Zetterstedt, 1846): 48 - male abdominal sternite $5 ; 49$ - male cerci and surstyli (caudal view); 50 - penis apparatus with pregonites, postgonite and epiphallus; 51 - female abdominal sternites 8 to 5 . Scale bars $0.5 \mathrm{~mm}$ (Figs 48, 49, 51); $0.1 \mathrm{~mm}$ (Fig. 50). 
dity of Scathophaga villipes (Zetterstedt, 1846) is confirmed in this paper.

\section{Species excluded from Scathophaga}

\section{Coniosternum lapponicum Ringdahl, 1920}

Coniosternum lapponicum Ringdahl, 1920: 39

Scathophaga minuta Malloch, 1935: 255, syn. nov.

Material examined. Scathophaga minuta. CANADA: Que. [Quebec], Indian House L.[Lake], 4.viii.1954, 1 m*, W. R. Roberts leg., J. R. Vockeroth 2003 det. as S. minuta (FSPC).

Diagnosis. Male. Cerci distinctly separated, surstyli in equal length as cerci, lobes of sternite 5 arched inwards, pregonite with two apical bristles. Female. Sternite 7 quadrate, sternite 6 rectangular, sternites 8 pointed apically (cf. Šifner 2013: 215, Figs 45-47).

Distribution. Czech Republic (Šifner 2008), Mongolia (Gorodkov 1974), Russia (Gorodkov 1986), Sweden (Hedström 1991). Nearctic Region (Vockeroth 1965).

Comment. The transfer of Scathophaga minuta to the genus Coniosternum is based on the shape of the male terminalia, which are typical for the genus Coniosternum (cf. Šifner 1975, 1981, 2013). This specimen was determined by Vockeroth in 2003 as S. minuta Malloch; I compared the characters with the original description by Malloch, and with the characters of Coniosternum lapponicum Ringdahl. I see their characters as identical (cf. Šifner 2013) and propose the above-mentioned synonymy.
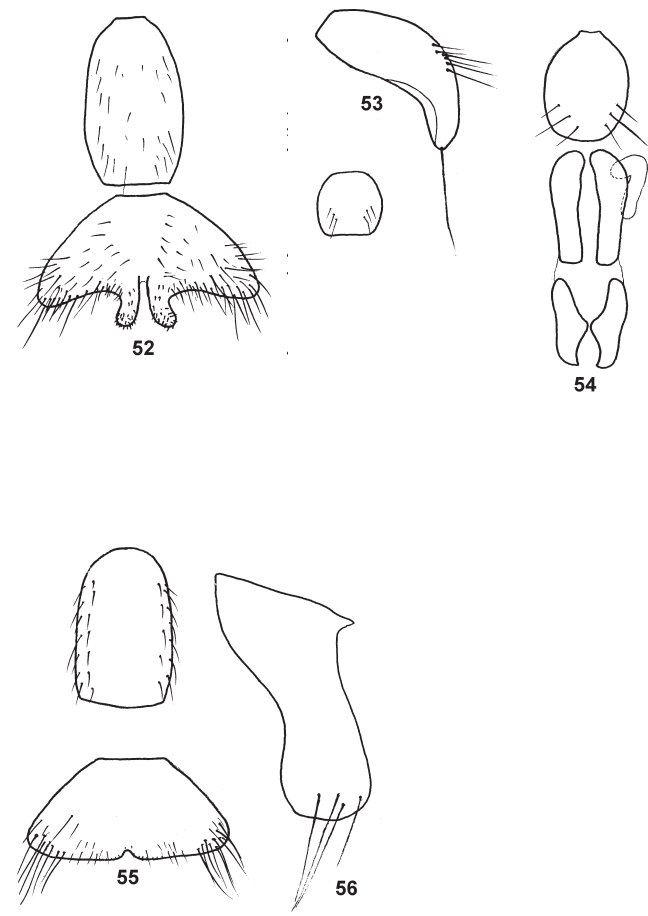

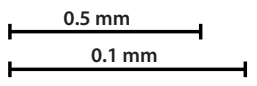

Figs 52-54. Scathophaga suilla (Fabricius, 1794). 52 - male abdominal sternites 5 and 4; 53 - right pregonite; 54 - female abdominal sternites 8 to 6 with spermatheca. Scale bars: $0.5 \mathrm{~mm}$ (Figs 52, 54); $0.1 \mathrm{~mm}$ (Fig. 53, (Figs. 52-54 originally from Šifner 2003).

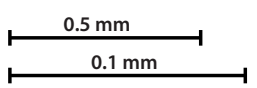

Figs 55-56. Scathophaga lutaria (Fabricius, 1794). 55 - male abdominal sternite 5 and 4; 56 - right pregonite. Scale bars: $0.5 \mathrm{~mm}$ (Fig. 55 ); $0.1 \mathrm{~mm}$ (Fig. 56). (Figs. 55, 56 originally from Šifner 2003). 

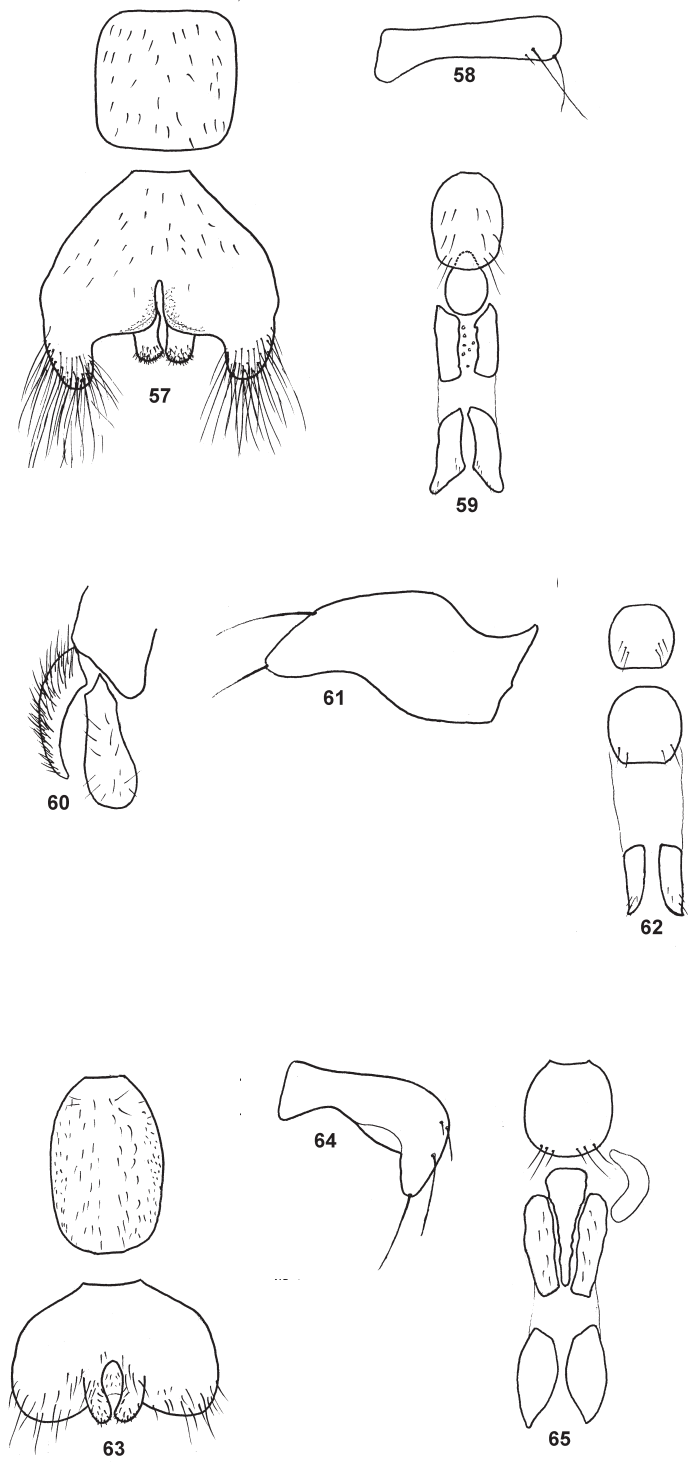

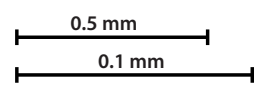

Figs 57-59. Scathophaga stercoraria (Linnaeus, 1758). 57 - male abdominal sternite 5 and 4; 58 - right pregonite; 59 - female abdominal sternites 8 to 6. Scale bars: $0.5 \mathrm{~mm}$ (Figs 57, 59); 0.1 $\mathrm{mm}$ (Fig. 58). (Figs. 57-59 originally from Šifner 2003).

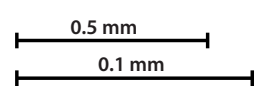

Figs 60-62. Scathophaga obscurinervis (Becker, 1900). 60 - cercus and surstylus (caudal view); 61 - left pregonite; 62 - female abdominal sternites 8 to 6 . Scale bars: $0.5 \mathrm{~mm}$ (Figs 60, 62); $0.1 \mathrm{~mm}$ (Fig. 61). (Figs. 60-62 originally from Šifner 2003).

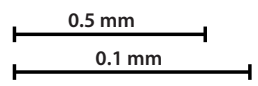

Figs 63-65. Scathophaga furcata (Say, 1823). 63 - male abdominal sternites 5 and $4 ; 64$ - right pregonite; 65 - female abdominal sternites 8 to 6 with spermatheca. Scale bars: $0.5 \mathrm{~mm}$ (Figs 63, 65); 0.1 $\mathrm{mm}$ (Fig. 64). (Figs. 63-65 originally from Šifner 2003).

Coniosternum molle (Becker, 1894), comb. nov. 
Material examined. MONGOLIA: Alag Mart, 4 km NO Pass Chadzen Sogotyn, Tesijn gol, $1 \mathrm{~m} *, 1900 \mathrm{~m}$ a.s.l., F. Šifner det. as S. mollis (FSPC). CANADA: Fort Churchill, 3.vi.1952, $1 \mathrm{f*}$, F. R. Eburlich leg., J. R. Vockeroth det. as S. mollis (FSPC).

Diagnosis. Male. Lobes of abdominal sternite 5 narrow, with long hairs, medially with short processes, sternite 4 quadrate (Fig. 66), cerci and surstyli of equal length, both pointed, surstyli arched (Fig. 67), pregonite with two setae (Fig. 68). Female. Abdominal sternites 8 narrow and pointed, sternite 7 rounded caudally, sternite 6 oval (Fig. 69).
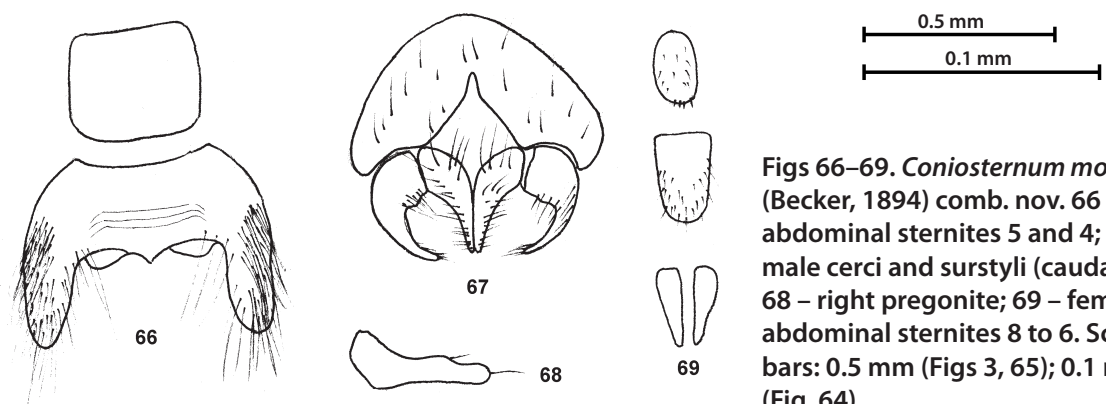

Figs 66-69. Coniosternum molle (Becker, 1894) comb. nov. 66 - male abdominal sternites 5 and 4; 67 male cerci and surstyli (caudal view); 68 - right pregonite; 69 - female abdominal sternites 8 to 6 . Scale bars: $0.5 \mathrm{~mm}$ (Figs 3, 65); $0.1 \mathrm{~mm}$ (Fig. 64).

Distribution. Canada (Malloch 1935), Mongolia (Šifner 1975), Russia (Becker 1894, Ozerov 2010).

Comment. The transfer of Scathophaga mollis to the genus Coniosternum is based on the shape of the male terminalia, which are typical for the genus Coniosternum.

\section{Coniosternum nigripalpis (Becker, 1907), comb. nov.}

Scatophaga nigripalpis Becker, 1907: 413

Scopeuma orbitalis Becker, 1915: 65 (syn. Gorodkov 1986: 33)

Scatophaga picipes Malloch, 1935: 263 (syn. Vockeroth 1965: 839)

Material examined. CANADA: Forsheim Creek, Hof Weather Creek, iv.1991, 1 m* (FSCP); Ellesmere Is., Forsheim Pen, Hot Weather Creek, 1991, 1 f*, all F. Brada leg., J. R. Vockeroth det. as S. nigripalpis (FSPC).
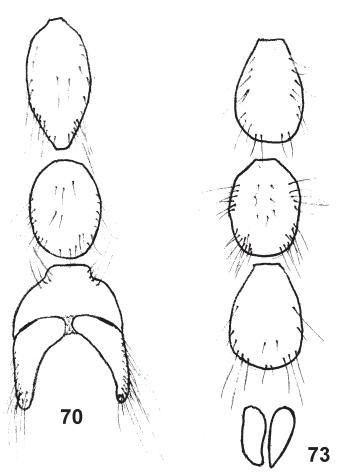
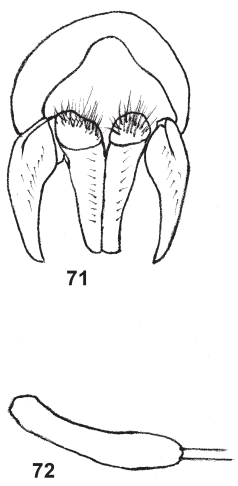

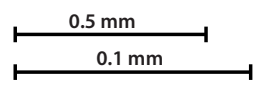

Figs 70-73. Coniosternum nigripalpis (Becker, 1907). 70 - male abdominal sternites 5 to $3 ; 71$ - male cerci and surstyli (caudal view); 72 - right pregonite; 73 - female abdominal sternite 8 to 5 . Scale bars: $0.5 \mathrm{~mm}$ (Figs 70, 71, 73); $0.1 \mathrm{~mm}$ (Fig. 72). 
Diagnosis. Male. Lobes of abdominal sternite 5 narrow, rounded apically, laterally with long hairs, sternites 4 and 3 oval (Fig. 70), cerci fused and of equal length as surstyli (Fig. 71), pregonite with two apical setae (Fig. 72). Female. Abdominal sternite 8 pointed caudally, sternites 7 to 5 more or less oval and bristled (Fig. 73).

Distribution. Russia, North Europe, Greenland, Canada (Vockeroth 1965); USA (Vockeroth 1965).

Comment. The transfer of Scatophaga nigripalpis Becker, 1907 to the genus Coniosternun is based on the shape of the male terminalia, which are typical for the genus Coniosternum.

\section{Acknowledgements}

I would like to thank to Jan Máca (Veselí nad Lužnicí, Czech Republic) for access to material from Svalbard used in this work, to Petr Kment and Michal Tkoč (National Museum Praha) for critical comments on the manuscript and digital processing of the figures, and to my son Mirek for his continuing technological help.

\section{References}

Beckert T., 1894: Dipterologische Studien. I. Scatomyzidae. - Berliner Entomologische Zeitschrift 39: 77-196.

Beckert T., 1905: Holometopa. Acalyptera. Scatomyzidae. Pp. 1-21. - In: Becker T., Bezzi M., Kertéz K. \& Stein P. (eds.): Katalog der paläarktischen Dipteren. Vol. IV. Budapest, 328 pp.

Beckert T., 1907: Ein beitrag zur Kenntnisder Dipterenfauna Nord Sibiriens. - Mémoires de l'Academie Impérial des Sciences de St. Pétersburg 2: 396-404.

Collin J.E., 1931: The Oxford University Expedition to Groenland, 1928. Diptera (Orthorrhapha Brachycera and Cyclorrhapha) from Groenland. - Annals and Magazine of Natural History, Series 10, 7: 67-91.

Collin J.E., 1935: Diptera (Cyclorrhapha) from Akpatok Island, Ungava Bay, Canada. Results of the University Hudson Straight Expedition. - Annals and Magazine of Natural History, Series 10, 15: 369-380.

Coquillett D.W., rok: New Diptera in the U. S. National Museum. - Proceedings of the United States National Museum 23: 593-618.

Cresson XX 1918: New North American Diptera (Scatophagidae). - Entomological News and Proceedings of the Entomological Section of the Academy of Natural Sciences of Philadelphia 29: 133-137.

Curtis J., 1832: British Entomology. London, Vol. 9: pl. 405.

Draber-Mońko A., 1991: Scatophagidae. Pp. 231-233. - In: Rakowski J. (ed.): Wykaz zwierzat Polski. [Checklist of animals of Poland]. Vol. 2. WPN Ossolineum, Wrocław - Warszawa Kraków, 342 pp. [in Polish]

Gorodkov K.B., 1974: Materialy po faune Scatophagidae (Diptera) Mongol'skoy narodnoy respubliki. (Scatophagidae (Diptera) of Mongolian People's Republic). - Nasekomye Mongolii 2: 380-395. [in Russian, English title]

Gorodkov K.B., 1986: Family Scathophagidae. Pp. 11-41. - In: Soós A. \& Paap L. (eds.): Catalogue of Palaearctic Diptera, Vol. 11. Akadémiai Kiadó, Budapest, 346 pp.

Hackman W., 1956: The Scathophagidae (Diptera) of Eastern Fennoscandia. - Fauna Fennica Vol. 2. Societas pro Fauna et Flora Fennica, Helsingfors, 67 pp.

Hackman W., 1980: A check list of the Finnish Diptera. II. Cyclorrhapha. - Notulae Entomologicae 60: 117-162.

Hansen H.J., 1881: Faunula Insectprum Faeorensis: fortegnelse over de paa Faeroerne hidtil samlede insekter. - Naturhistorisk Tidskrift 13: 229-280.

Haliday A.H., 1832: The characters of two new dipterous genera, with indications of some generic subdivisions and several undescribed species of Dolichopodidae. - Zoological 
Journal (London) 5: 350-367.

Hedström L., 1991: Svenska insektfynd - rapport 7. (Swedish insect records - report 7). Entomologisk Tidskrift 112: 133-146. [in Swedish, English abstract]

Henriksen K.L., 1917: Groenlands Landarthropoden (Insecta et Arachnida Groenlandica). Medellelser om Groenland 22: 483-821.

Holmgren A.E., 1883: Diptera. Pp. 143-161. - In: Holmgren A.E. \& Aurilius C.: Insecta a viris doctissimis Nordenskiöld illem ducem sequentibus in insuli Waigatsch et Novaja Semlija anno 1875 collecta Hymenoptera et Diptera. - Entomologisk Tiskrift 4: 139-194.

ICZN 1963: Opinion 678. The suppression under the Plenary Powers of the pamphlet by Meigen, 1800. - Bulletin of Zoological Nomenclature 20: 339-342.

James M.T., 1950: The genus Scopeuma in the Western United States and southwestern Canada. - Annals of the Entomological Society of America 43: 243-253.

Jong H. de, 2000: The Scathophagidae (Diptera) described by F. M. van der Wulp and J. C. H. de Meijere. - Studia Dipterologica 1: 149-154.

Jong H. de, 2005: Fauna Europaea: Diptera Brachycera. Fauna Europaea version 1.2. Available online at http://www.faunaeur.org. [Last update: 7 March 2005]

Lindrith C.H., 1931: Die Insektenfauna Islands und ihre Probleme. - Zoologiska Bidrag från Uppsala 13: 105-599.

Lundbeck., 1901: Diptera groenlandica. - Videnskabelige Meddelelser fra den Naturhistoriske Forening i Kjobenhavn, Series 6 1900: 281-316.

Malloch J.R., 1919: Exotic Muscaridae (Diptera). - Annals and Magazine of Natural History, Series 10, 8:425-446.

Malloch J.R., 1931: LIX.- Exotic Muscaridae (Diptera). - XXXV. Family Muscidae. Subfamily Scatphaginae. - Annals and Magazine of Natural, Series 10, 8: 425-439.

Malloch J.R., 1935: XXI.- Exotic Muscaridae (Diptera). - XXXVIII. Family Muscidae. Subfamily Scatophaginae. - Annals and Magazine of Natural, Series 10, 86: 242-266.

Michelsen V., 2006: Annotated catalogue of the Anthomyiidae, Fannidae, Muscidae and Scathophagidae. - Stenstrupia 29: 15-126.

Morge G., 1976: Diptera collectionis P. Gabriel Strobl - IX. Supplementa ad Partes I et V. Beiträge zur Entomologie 26: 531-541.

Nelson J.M. \& Greve L., 2002: New species of dung flies (Diptera, Scathophagidae) from Norway with a checklist of the Norwegian Scathophagidae. - Norwegian Journal of Entomology 49: 41-47.

Ozerov A.L., 2010: Five new species of Scathophagidae (Diptera) from Russia. - Russian Entomological Journal 19: 157-166.

Ozerov A.L., 2014: The primary types of Scathophagidae (Diptera) in the Museum für Naturkunde Berlin, and Senckenberg Deutsches Entomologisches Institut, Germany. Zoosystematics and Evolution 90: 33-43. https://doi.org/10.15298/rusentj.23.4.06

Ozerov A.L. \& Krivosheina M.G., 2013: Types of Scathophagidae (Diptera) at the Zoological Institute of Russian Academy of Sciences, St. Petersburg. - Zoologica Rossica 22: 1-10.

Pandellé L., 1904: Catalogue des Muscides de France. - Revue d'Entomologie 23 (Suppl.): 1-34.

Ringdahl O., 1937: Neue Namensanderung. - Entomologisk Titskrift 58: 38.

Ross J., 1835: Narrative of a second voyage in research of a North-West Passage and of residence in the Arctic Regions during the years 1829, 1830, 1831, 1832, 1833. Appendix.

- Lon don: Natural History, cxliv pp.

Sack P., 1937: 62a. Cordyluridae. - In: Lindner E. (ed.): Die Fliegen der Palaearktischen Region. Vol. 7. E. Schweizerbart'sche Verlagsbuchhandlung (Erwin Nägele), Stuttgart, 103 $\mathrm{pp}+6$ pls.

Say T., 1823: Description of dipterous Insects of the United States. - Journal of the Academy of Natural Sciences of Philadelphia 3: 38-66, 73-104.

Šifner F., 1975: Scatophagidae (Diptera) de Mongolie. - Annales Historico-Naturales Musei 
Hungarici 67: 219-227.

Šifner F., 1981: Les résultats de l'expédition entomologique Tchécoslovaque-iranienne a l'Iran en 1973. (Avec le description d'une espece nouvelle du genre Coniosternum d'Albanie et avec le tableau analytique des especes du genre Coniosternum Becker, 1894 paléarctique). - Acta Entomologica Musei Nationalis Pragae 40: 95-104.

Šifner F., 2003: The family Scathophagidae (Diptera) of the Czech and Slovak Republics (with notes on selected Palaearctic taxa). - Acta Musei Nationalis Pragae, Series B - Historia Naturalis 59: 1-90.

Šifner F., 2008: A Catalogue of the Scathophagidae (Diptera) from the Palaearctic region, with notes on their taxonomy and faunistics. - Acta Entomogica Musei Nationalis Pragae 48: 111-196.

Šifner F., 2011: Two new species of Scathophagidae (Insecta: Diptera) from the Czech Republic, with description of the males of Scathophaga bohemiae and Norellisoma vonickai. - Journal of the National Museum (Prague), Natural History Series 180: 31-38.

Teschener D., 1965: Beitrag zur Dipterenfauna von Spitzbergen. - Zoologischer Anzeiger 175: 364-366.

Vockeroth J.R., 1956: Distribution patterns of the Scatomyzinae (Diptera, Muscidae). Proceedings of Tenth International Congress of Entomology 1: 619-626.

Vockeroth J.R., 1965: Subfamily Scathophaginae. Pp. 826-842. - In: Stone A., Sabrowsky C.W., Wirth W.W., Foote R.H. \& Coulson J.R. (eds.): A catalog of the Diptera of America north of Mexico. Agricultural Handbook No. 267. Agricultural Research Service, United States Department of Agriculture, Washington, D.C., 1696 pp. 